Florida International University FIU Digital Commons

FIU Electronic Theses and Dissertations

University Graduate School

$10-26-2015$

\title{
Stephen Dedalus' Search for Identity in Catholic Ireland
}

Cristina L. Cuevas

Florida International University, ccuer011@fiu.edu

DOI: 10.25148 /etd.FIDC000149

Follow this and additional works at: https://digitalcommons.fiu.edu/etd

Part of the English Language and Literature Commons

\section{Recommended Citation}

Cuevas, Cristina L., "Stephen Dedalus' Search for Identity in Catholic Ireland" (2015). FIU Electronic Theses and Dissertations. 2258.

https://digitalcommons.fiu.edu/etd/2258

This work is brought to you for free and open access by the University Graduate School at FIU Digital Commons. It has been accepted for inclusion in FIU Electronic Theses and Dissertations by an authorized administrator of FIU Digital Commons. For more information, please contact dcc@fiu.edu. 


\title{
FLORIDA INTERNATIONAL UNIVERSITY
}

Miami, Florida

STEPHEN DEDALUS' SEARCH FOR IDENTITY IN CATHOLIC IRELAND

\author{
A thesis submitted in partial fulfillment of \\ the requirements for the degree of \\ MASTER OF ARTS \\ in \\ ENGLISH \\ by
}

Cristina Cuevas 
To: Dean Michael R. Heithaus

College of Arts and Sciences

This thesis, written by Cristina Cuevas, and entitled Stephen Dedalus' Search for Identity in Catholic Ireland, having been approved in respect to style and intellectual content, is referred to you for judgment.

We have read this thesis and recommend that it be approved.

Meri-Jane Rochelson

Nathaniel Cadle

Michael Gillespie, Major Professor

Date of Defense: October 26, 2015

The thesis of Cristina Cuevas is approved.

\begin{tabular}{r}
$\begin{array}{r}\text { Dean Michael R Heithaus } \\
\text { College of Arts and Sciences }\end{array}$ \\
\hline Dean Lakshmi Reddi \\
University Graduate School
\end{tabular}

Florida International University, 2015 


\section{DEDICATION}

I dedicate this thesis to my husband who never had the opportunity to go to college despite being a true intellectual and lover of learning. I thank him for reading my papers, and for encouraging me with his favorite refrain, “Cristina, if it was easy everyone would do it.” His evident pride in my academic pursuits gave me the confidence to persevere.

I also dedicate this to my students whose youthful energy is infectious. I am so privileged to be able to work with young people who constantly renew my faith in the future of humanity. 


\section{ACKNOWLEDGMENTS}

I never would have predicted, upon entering the graduate program, that the subject of my thesis would be a work by Joyce. I had never read his works beyond “Araby” which is in my classroom’s textbook. I did not enjoy teaching "Araby,” because I did not understand it. Going in to Dr. Gillespie’s course felt like a daunting challenge, but it turned out to be a truly enlightening experience. Dr. Gillespie’s humor made the reading approachable, hence enabling me to invest in the literature. I went on to write about Joyce's works in other classes, and grew more and more passionate about his characters and modern style. I now not only teach “Araby,” but all of DUBLINERS and by the time we finish “The Dead,” I know many of my students are hooked as well.

I would also like to acknowledge how grateful I am to Dr. Gillespie for serving as the major professor on this committee. I appreciated his recommendations on reading selections. His astute suggestions were in line with my project, so I never felt overloaded with a mountain of paper, rather that I was on track. I am so thankful that he quickly turned over my drafts with helpful revisions and words of encouragement. I know I have become a stronger writer from working with him.

I began graduate school with Dr. Rochelson’s course on the late Victorians. Learning about emerging modernism laid the groundwork for this period of literature that captivates me. A group project on race in that class opened my eyes to colonial discourse, which subsequently led to future papers on that subject. It was a thrilling dynamic project, which also demanded that I delve into the microfiche archives. Conducting that research demanded that I spend a lot more time on campus. In that way, 
after a decade since my undergraduate years, I was once again immersed in university life. Dr. Rochelson was also my advising professor for admittance to the graduate program. Her thoughtful feedback and guidance on my submission essay is deeply appreciated.

Dr. Cadle's course on print media came at a time in my graduate career when I was feeling a little burned out. Although I was enjoying my classes, I was smack dab in the middle of my program, and tired of the hour-long commute. Introducing us to the Wolfsonian Museum’s archives renewed my love of original research. I eagerly visited the museum several times, and I was captivated by the research process. I also learned to be a better reader and critical thinker from Dr. Cadle’s methods. Every part of the magazines we studied became text that could be analyzed, including the artwork, prioritizing of author placement, and font. This experience changed the way I read not just literature, but the world.

Dr. Milbauer was the first professor I met in the department. His demeanor conveyed a professionalism and high standards that convinced me to enter the program. I appreciate his thoughtful advisement and encouragement.

All of my professors and classmates have contributed to what for me has been a life changing experience. Thank you. 


\begin{abstract}
OF THE THESIS
STEPHEN DEDALUS’ SEARCH FOR IDENTITY IN CATHOLIC IRELAND by
\end{abstract}

Cristina Cuevas

Florida International University, 2015

Miami, Florida

Professor Michael Gillespie, Major Professor

The purpose of my research was to explore the interplay between religion and art in James Joyce’s novel, A PORTRAIT OF THE ARTIST AS A YOUNG MAN. My aim was to trace the development of the protagonist, Stephen Dedalus by analyzing how Catholicism is an institution that forms him, yet must reject to realize his artistic potential. I researched Joyce's background to gain an understanding of the exilic experience on the literature. Through the exilic lens, I realized that Catholicism was the predominant influence on Stephen's need to embark on a self-imposed exile at the end of the novel. Complicating his decision is the fact that he does not stop believing in religious constructs such as heaven and hell. In conclusion I found by following his artistic longing, and turning away from the church he is committing a sin and, as a result, damning his soul. 


\section{TABLE OF CONTENTS}

CHAPTER

PAGE

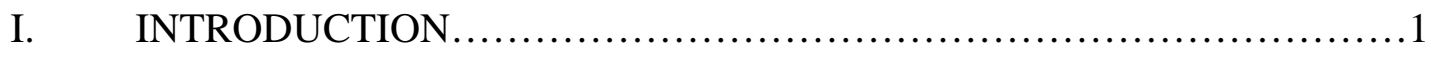

II. CHAPTER ONE: Stephen's Perception of Jesuits \& Family...................12

III. CHAPTER TWO: Conformity \& Rebellion Leading to Epiphany...........27

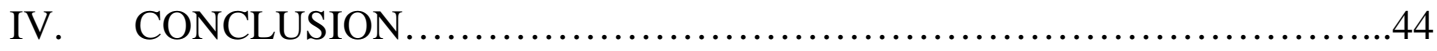

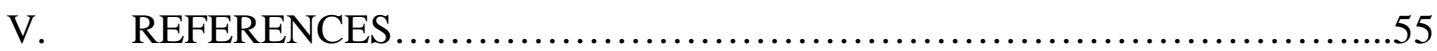




\section{INTRODUCTION}

James Joyce's Roman Catholic education is reflected in the experiences of Stephen Dedalus, the hero of his novel, A Portrait of the Artist as a Young Man. Joyce's Jesuit-led education is revealed as Stephen's conflict with the crux being the internal war waged within the character as one who is cultivated in a prescribed and duteous Catholic upbringing, yet whose artistic aspirations run counter to this society's expectations of him. Just as Joyce's relationship with the Jesuits and church cannot be summed up as a simple affinity or rejection of their tenets, neither can his hero's. Stephen Dedalus, like Joyce, is reared within the Catholic framework of Clongowes Wood College, Belvedere College, and University College, Dublin, and therefore his worldview is constructed in a manner that reflects the problematic ironies existing between the educational agenda of the Jesuits and the social conflicts of Ireland during the late nineteenth and early twentieth centuries. I will elaborate upon these discrepancies regarding political, filial, and religious ties in the novel as I follow the novel's progression toward Stephen's epiphany that while his belief in Catholic principles is something he believes in, he must ultimately reject religious practices in order to pursue a life as an artist. Meaning, he believes in heaven and hell, and the concept of his eternal soul, but the rigidity of the church does not allow him to experience truth as an artist without sinning. This paradox forces him to choose between the fate of his soul and his artistic aspiration. His

perspective throughout the novel, as he matures and comes to understand the world, enables him to negotiate the terms of his exile at the end.

The conflicts Stephen faces are consequences of an educational and religious foundation mired in contradictions that test traditional Irish nationalism against a British 
empirical authority. Stephen belongs to an emerging middle class, which at times must comply with the colonial model to survive socially. It is in the best interest of members of Stephen's socioeconomic class to temper their Irish Catholic pursuit within a framework supported by Britain. At the institutions Stephen attends, students will pursue careers as magistrates and other positions that align with a British ruled government. In the novel, Stephen's father Simon puts his faith in the Jesuits' ability to rear young men who can play this diplomatic game, satisfying both the rules of Catholicism and the British authority. Therefore, Stephen's burgeoning self-awareness as an artist is both despite of and because of the Jesuit instruction he receives. Stephen vacillates between following the Jesuit mission and rebelling against it. The basis of my thesis is to investigate the manner in which Stephen reconciles with the balance of what is at stake, namely his soul and artistic ambition. Ultimately, he realizes that his search for artistic validation requires him to alienate himself from the Catholic community as a necessary measure toward great artistry.

Historically, education in Ireland was motivated by a desire to cultivate literate citizens. To understand the extent that Joyce's Catholicism affected his educational upbringing as evident in his literature, it is helpful to review the historical beginnings of education in Ireland. The education initiative was backed by Protestants and Catholics alike, and both groups had their own mission in addition to literacy. In his article "Education and Social Class in Joyce’s Dublin,” Patrick Ledden explains the goal behind educating Ireland's illiterate poor. In 1800 the privately funded, Protestant backed, Kildare Place Society had an agenda that was viewed by the Roman Catholic clergy as designed, "to wean Roman Catholic children away from their superstitious and disloyal 
religion” (Ledden 330). The Protestant agenda spurred the formation of the Christian Brothers Order, "a group of men pledged to poverty and communal living who devoted their lives to the Catholic education of the poor" (Ledden 330). Because both groups' schools were accessible to the poor, these schools carried a socioeconomic stigma (Ledden 331); therefore alternatives grew for more affluent citizens:

Schools maintained by a variety of religious orders of priests, monks, and nuns Clongowes Wood and Belvedere being good examples - catered to the children of the growing Catholic middle class. Various endowed schools with roots in the Ascendancy past were available to protestant children. And, of course, some prosperous parents sent their children to English schools. (Ledden 332)

Joyce attended both Clongowes and Belvedere fortifying his early development with the influence of the Jesuits as instrumental role models. Jesuit approach to education privileged the soul over political insurgency. Kevin Sullivan’s Joyce Among the Jesuits, clarifies that the Jesuits' middle class pupils, of whom Joyce was one, who attended the private institutions, came from affluent households. Since these were supported by the British ruled status quo, it was counterproductive to pursue a radical curriculum (23). In a pragmatic fashion, the Jesuits compromised, disposing of a political agenda in favor of an emphasis on salvation:

They were not conducting a school for young rebels, agitators, or a revolutionary breed of native patriots. Had they thought to do so, they would quickly enough have found themselves without school or students. Finally, if any of them ever reflected that in terms of the national struggle their curse was less than heroic, 
they had the consolation of their Jesuit vows, which pledged them to the salvation of souls, not to the saving of Ireland. (Sullivan 24)

Adding support to the complexity of religion's social influence in Irish education in the nineteenth century is the Protestant colonial pressure for a non-sectarian network of national schools. In his article, "Ireland, Europe, the World, the Universe: Political Geography in A Portrait of the Artist as a Young Man” Jason Howard Mezey makes the point that the Jesuits who ran Clongowes did not have complete autonomy. Mezey explains:

However, as a result of the Intermediate Education Act in 1878, the Intermediate Education Board of Ireland was established to oversee the awarding of financial prizes to pupils and institutions based on a series of standardized examinations. In order to be eligible for these awards, Clongowes had to adapt its educational curriculum to match the priorities set forth by the IEBI. (Mezey 341) Mezey's research supports Ledden's in that Clongowes was a conservative Catholic institution and abided the English colonial objective to tamp down Irish Catholic tradition among the middle class, as opposed to some of the more radically nationalistic free public schools such as the Christian Brothers, which rebelled by teaching the Celtic language (Mezey 342). As educated men who traveled extensively, the Jesuits who ran Clongowes were possibly more willing to adopt the IEBI's teaching methods given their potentially more open-minded worldview (Mezey 342). Thus the Jesuits masterfully harmonized a Catholic education in accordance with political expectations of their middle class students. 
It seems that compliance with colonial pressures and the pervasiveness of Catholicism as the primary influence on culture, are motivating factors that contradict one another, because Irish Catholicism encompasses nationalistic pride as a component, but as Mezey’s article and Sullivan's book support, these are just the types of ambiguities that are critical to Stephen's upbringing and why we will see him struggle later with determining his identity. The novel A Portrait of the Artist as a Young Man is contextually nestled within an Irish Catholic tradition that shapes the ideology and creates a lens through which the characters view their culture. These external factors combine with Stephen's cleverness compelling him to grapple with the righteousness of Catholic doctrines, and how the adults in his life quixotically approach religion and politics. These adult role models, namely the priests and his family, operate and speak in a manner that puzzles Stephen and forces him to analyze the disparity between their language and actions. As Stephen grows, his scrutiny evolves and he moves away from the blind faith in Catholicism he has followed as a child. In adolescence, Stephen attempts to tamp down his individualism by denying his artistic identity. He tries to strictly adhere to the tenets of Catholicism for a time because an easier path would be one in which he complied with religious order. During this period, he seeks solace in a monastic routine modeled by the Jesuits. This ritualistic practice is short-lived, because although Stephen will garner favorable attention from the priests, when he is approached about joining the order, he faces a traumatic epiphany that directs him away from the church. Illuminated by his realization, it is with elation that Stephen realizes that alienation from the church is the only course toward his calling as an artist. Stephen's epiphany motivates him to prepare for a self-imposed exile in order to foster his artistry. 
Given the friction between Catholicism and social class within Irish culture it is not surprising that Stephen creates ways to construct his notion of himself in regards to his location. He ponders what lies beyond the known. As the title of Mezey's article alludes, it is a list that Stephen creates in his notebook that foreshadows his lifelong compulsion to determine his place in relation to Irish society:

\section{Stephen Dedalus}

Class of Elements

Clongowes Wood College

Sallins

County Kildare

Ireland

Europe

The World

The Universe (Joyce 13)

Mezey's point in observing Stephen's list is to highlight the omission of England following Ireland as an act of anti-colonial rebellion. While I am not approaching Stephen's list with that in mind, I would add that, geographically, Stephen tops the list with his school affiliation immediately following his name, demonstrating the impact of the Jesuits' special brand of Catholic education with an emphasis on the intellect that influences Stephen's perspective on self. Joyce differentiated between mainstream Catholicism and the Jesuits when he corrected his friend Frank Budgen's biography by stating, "'You allude to me as a Catholic. Now for the sake of precision and to get the correct contour on me, you ought to allude to me as a Jesuit’” (Ellmann 27). Even 
though the novel shows numerous ways that the Jesuits terrify Stephen, he admires them. Since the special ministry of the Jesuits is in education and leadership (capuchinfranciscans.org), Jesuit led instruction is the launching place from which Stephen will comprehend his place in the world. Religion as a mechanism of institutional control acts as what Mezey describes as hegemony over Stephen's mind when he quotes Vincent Cheng's book Joyce, Race, and Empire:

For Stephen, too, religion is a very major element within the hegemonic powers of institutional authority which would hold sway and empire over him - not only because of the Church's direct role in Irish politics (as in the Parnell affair) and in betraying the Irish cause ... but also because the Church represents for Stephen a generalized authority and empire over his mind and person. (Mezey 347)

However, regardless of the empirical authority the Jesuits have over Stephen's mind, he is able to step back and evaluate their hegemonic control. Therefore, it serves as a testament to Stephen's courage when despite his deep-rooted reverence in the sovereignty of the priests, he is able to demonstrate his resistance and challenge them when he feels they have treated him unfairly. Furthermore, it is important to lay this groundwork to emphasize the radical insurgency on Stephen's part when he ultimately turns his back on the rituals of Catholicism - essentially his culture - in pursuance of art.

Just as Stephen's list lays out a personal geography, so does his placement of words function as a tool to manipulate language as a strategy to create meaning. In the case of the list, attention to language outlines the position of his body toward the greater universe. My discussion of words as a tool in the novel will pay careful attention to the novel's play with language as a gateway for Stephen's understanding of his world. As 
Nicholas Fargnoli and Michael Gillespie explain in their book Critical Companion to James Joyce: A Literary Reference to His Life and Work, for Joyce this writing style emerged following completion of Dubliners in 1907 with an evolution of a narrative via personalized everyday events to achieve a deeper relevancy between the work and the reader:

To exploit this potential he discarded the limitations of the realistic form and experimented with a looser and formally more flexible style, now recognizable as a characterizing feature of English modernism, that relied heavily on the active participation of readers in the process of forming a unified narrative. (Fargnoli, Gillespie 135)

Thus, Stephen approaches meaning in the mundane and often overlooked facets of life. With this ability to reflect within moments of triviality, Stephen's epiphany is revealed to him: "For Joyce, the word epiphany designated a moment of spiritual revelation or showing forth of one’s true self” (Fargnoli, Gillespie 273). Furthermore, Joyce executes this through his stylistic tendency to show an object rather than offer a scripted narrative biased with pretext. In The Implied Reader, Wolfgang Iser writes that Joyce's reticent aim evolves, "those aspects of an object that are kept concealed by the perspective mode of observation” (191). Removing all superfluous context jars the reader with strange word usage and forces a new perspective to reveal a facet of truth perhaps previously obscured or assumed as a presumption of the status quo. Discursive reduction is how Stephen establishes context. It is helpful to discuss Joyce's style in relation to how it conveys Stephen's method of approaching his understanding of the world, which is to say he hyper focuses on objects and words, which normally tend to be overlooked as trivial 
and mundane. Within a space of comprehension he seeks his artistry, and therefore it stands to reason that he cannot abide Catholicism’s tenets, because to abide Catholicism would be to adhere to exacted lists and rules without question and without investigation.

Young Stephen contemplates the absence that lies beyond the known universe when he rereads his list backwards, "then he read the flyleaf from the bottom to the top till he came to his own name. That was he: and he read down the page again. What was after the universe? Nothing. But was there anything round the universe to show where it stopped before the nothing place began?” (Joyce 13). Language contemplation demonstrates Stephen's process as he contemplates his position by breaking down the known and the unknown. Joyce will put silence into the text in various forms, be it as absence or, in this case, the absolute darkness of outer space. When Stephen pauses and notices absence he pushes distractions aside in order to extrapolate the underlying truth. Stephen seeks meaning by delving into the dark absence to reach an epiphany. Looking at dead space, and overlooked words and objects is his way of coming to know something, and again, is why he longs for something more than the dictating structure of Catholicism can provide. Stephen's treatment of the list early on is instructive as a howto guide for viewing the manner in which he understands his placement in relation to Irish Catholic society.

The amount of religious dogma is so all encompassing that the other characters are unable to challenge the doctrine. In his article "Riddles Silence, and Wonder: Joyce and Wittgenstein Encountering the Limits of Language” author Thomas Singer compares Joyce’s approach to language with the Tractatus Logico-Philosophicus, the notebooks of Ludwig Wittgenstein, a Viennese philosopher serving as a soldier in the Austro- 
Hungarian army. Singer posits that Joyce and Wittgenstein’s ventures in ambiguous language mirrored each other. Singer points out that because everyday language is so prescribed, these men used silence and riddles to exercise new meaning. The silent empty space Singer addresses is where epiphany lies in the novel, as he explains when he addresses puzzling language as a device:

Rather, the riddle is itself its own answer insofar as it is a sign that points silently to the miraculousness of existence, of wonder before the world that calls forth from us an affirmation of the spirit of life. Wittgenstein and Joyce are strikingly similar in the methods they employ to reawaken in us this feeling of wonder before the world. (Singer 460)

At an early age, Stephen views the list in awe when he considers his position in the universe. Supporting Fargnoli and Gillespie’s contention that Joyce found a source for his narrative in the everyday objects and motions of life, Singer similarly states of Joyce and Wittengenstein that, "What ties these two writers together above all else is their belief that the ordinary is the extraordinary, that the wonder of the world is not hidden behind any veils but is open to our view, and that language is both a revelation of this wonder and its riddle” (Singer 462). In that dead space of the overlooked and the absent, Stephen seeks to discover meaning, and ultimately his art. Stephen’s attention to language evolves as the novel progresses and enables him to comprehend his location and belongingness as well as support his resolve to embark on an exile to foster his artistic longing.

In the chapter that follows, my approach to the novel will be to identify three stages critical to Stephen’s development away from religious conventions toward artistry 
by examining how he discovers his relationship with the church given his unique reflective style. Within the first chapter, I address what young Stephen observes of the altercation at Christmas dinner, followed by Stephen's confrontation with Father Conmee. In Chapter Two I discuss moments when Stephen vacillates between conformity to Catholicism and rebellion from it. Stephen's attempts at piety leads to the inducement on the part of the director for Stephen to join the order. Finally, in my conclusion I analyze Stephen as he negotiates the terms of his exile and reconciles with his impending disembarkation from Ireland. These critical instances of Stephen's growth demonstrate the manner in which he balances the importance of his eternal soul versus his aesthetic ambitions. Reconciling his artistic calling and belief in Catholicism are not mutually exclusive endeavors, rather they are superimposed on each other, and as on a palimpsest, when Stephen embarks on his self-imposed exile, the traces of Catholicism will never be erased. 


\section{CHAPTER ONE: Stephen’s Perception of Jesuits \& Family}

In this chapter I will address Catholicism as the bedrock to everything of social significance in Stephen’s community. As such, Stephen’s Catholic faith influences his identity. Analysis of the everyday, often overlooked, objects of life is the method he uses to reach an understanding of his place within this community. As a burgeoning artist, Stephen cultivates meaning by manipulating language in his search for truth. The truth he seeks is his artistic awareness, and as an artist, his artistic awareness is one and the same as his self-awareness. Sometimes Stephen's reflections take place within a kind of dead space, as when he contemplates what lies beyond the known universe. He contemplates bsence and dead space that represents the unknown, and he often questions what lies in that mysterious abyss. In this chapter I will demonstrate examples of Catholicism’s influence on his development with examples from his childhood. I will go into depth about how the Jesuits rear Stephen, and the complicated nature of his perception of them. Just as his relationship with the Jesuits will evolve out of these incidents, so will his understanding about the members of his family also change. I will elaborate upon the Jesuit and family interactions later in this chapter at which time I hope to prove that the more he observes the Jesuits and his family, the greater his estrangement from the Catholic Church will come to be.

As I discussed in the introduction, when Stephen contemplates the mystery of the universe's boundary, he questions what lies beyond its edge. He reassures himself that it is sufficient to be ignorant of what lies in the unknown because God holds the answers to unanswerable questions. In youth, the moments when Stephen’s inquisitive mind wanders toward possibilities outside of the framework of his instruction, he is perplexed 
until he solves his dilemma by putting his faith in God. Instilled in him by his religious education, is the overriding conviction that God holds the answers to questions of the universe and the nature of one's being. This is religious thinking, and makes further reflection unnecessary. During this period Stephen is still a little boy, and with age this manner of thinking will change. With growth through the experiences I will explain in this chapter, he will not be satisfied with the absolute certainty asserted by religion. However, while still a child, he is reassured that in a mysterious universe he can rely on a religious construct. As he grows, Stephen will not lose his conviction that God, heaven, and hell are real, what troubles Stephen is when he experiences independent thoughts that veer from the teachings of the church. As an example of his venture toward independence, he uses language to toy with his link to God after writing on the flyleaf of his geography book by inscribing his name upon it:

It could not be a wall but there could be a thin line there all round everything. It was very big to think about everything and everywhere. Only God could do that. He tried to think what a big thought that must be but he could think only of God. God was God’s name just as his name was Stephen. (Joyce 13)

Even though Stephen's ability to ponder is limited in his youth, it is significant that language brings him closer to identity placement and self-knowledge. The list is instructional to the reader, in that it emphasizes the way Stephen comes to know, in this case with language, laying out the method of language contemplation he will pursue to attain his art. Therefore, his comfort within the confines of an authoritative God symbolizes his youth, and the manner in which he reflects about the unknown hints at his determination to define, locate and artistically actualize. 
As a child, the stakes are such that it is in Stephen's interest to put his faith in Godly pursuits because the alternative is hell. Therefore at this stage for Stephen, the ultimate catastrophe is the possibility of damnation. In his biography, James Joyce, discussing Joyce’s childhood, Richard Ellmann writes of how as children, Joyce and his siblings would enact hellish scenarios:

Hell and its superintendent had already become useful histrionic counters for him. He loved to arrange little plays, and his brother Stanislaus's earliest memory was of playing Adam to the Eve of his sister Margaret ('Poppie'), while James crawled about them in the congenial role of serpent. (Ellmann 26) The role-playing reminds one of the foundational role hell as a consequence of sin played in Joyce's upbringing, and how it would later manifest as the primary conflict for Portrait's Stephen. As Stephen becomes more alienated and moves toward exile, since he cannot pursue artistry within the confines of Catholicism, he must sacrifice his soul and risk going to hell. This will be the subject of my second chapter when I discuss Stephen's epiphany and decision to leave Catholic Ireland. Chapter one will lay the groundwork for how he comes to make that decision. For now it is important to think of the soul and artistic longing as two ostensibly polar opposites, which Stephen grapples with during his childhood.

By looking at the forces that drove Joyce's self-imposed exile, we can better understand the trauma that disengaging from the church and his society is for Stephen. Traumatic because as the foundation of his society, Catholic Ireland is a restrictive world that stifles Stephen's artistic longing. Joyce felt similarly suffocated and the stagnation 
of his society compelled him to ask his girlfriend, Nora Barnacle to leave Ireland with him. Joyce's utter inability to thrive in Ireland is evident in his letter to Nora:

"When I was waiting for you last night I was even more restless. It seemed to me that I was fighting a battle with every religious and social force in Ireland for you and that I had nothing to rely on but myself. There is no life here - no naturalness or honesty. People live together in the same houses all their lives and at the end they are as far apart as ever ...” (Ellmann 176)

Joyce's self-imposed exile took him to the religiously diverse city of Trieste, Italy, at that time part of the Austro-Hungarian empire. John McCourt writes of the years when Joyce wrote Portrait in, The Years of Bloom: James Joyce in Trieste 1904 - 1920. He discusses how Joyce’s religious obsession never left him. McCourt quotes Umberto Eco's The Aesthetics of Chaosmos: The Middle Ages of Joyce, in which Eco writes that Joyce, "abandons the faith but not religious obsession. The presence of an orthodox past reemerges constantly in his works under the form of a personal mythology and with a blasphemous fury that reveals the affective permanence” (McCourt 59). Joyce’s disgust with Catholic Ireland, yet his compulsion to revisit its themes, emerges also through Stephen's relationship with the church. Stephen questions religious tenets, which make less and less sense to him as he ages.

Understanding Joyce's ambiguous feelings about Ireland underscores for the reader the difficulty of Stephen's decision to reconcile with his Irish Catholic community. Throughout his years in Trieste, Joyce visited a variety of Orthodox churches, and in the strangeness of foreign Catholic practices he was able to "think anew about the more familiar Catholic equivalents, which in turn became strange to him” (McCourt 60). By 
taking a step back from the Catholicism imposed upon him, he was able to view the foreign services, hence gaining a clearer perspective of his own Irish Catholicism. Robert Boyle S.J. in James Joyce's Pauline Vision, explains Joyce's treatment of Catholicism in his writing when he elaborates upon Joyce's assertion that to express the Irish experience, Catholicism must be approached with dual feelings of awe and disdain. Joyce rejects the church, yet is compelled to return as an observer in both a literal fashion and to obtain fodder for his subject matter:

Something of the same thing is true about what I see as the profoundest depths of Joyce's esthetic as it assumes flesh in his creative words. Unless it is seen against the positive as well as the negative aspects of Catholic feeling and thought and aspiration, it may appear as distorted or as shallow. Joyce as artist takes no polemical position. He is out to express his experience, a complex of many things, among them an experience and a knowledge of the positive aspects of Catholicism. He did not see Catholicism as simply an evil force frustrating and repressing the self. He did of course see that aspect, but he saw it against the background of Catholic aspiration to fulfill and complete the self beyond the limits of nature, even infinitely beyond. (47)

Reading the novel with this in mind adds to the complexity of Stephen's understanding of his place within Irish Catholic society. As Stephen will scrutinize the doctrines, so will his feelings about the Jesuits evolve and change as he ages.

The first episode I will address involves Stephen's reaction to corporal punishment doled out by Father Dolan. The events surrounding this incident speak to Stephen's complicated relationship with the Jesuits. Furthermore, Stephen is very young 
when this occurs, therefore he does not fully comprehend what is being discussed. Stephen's conception of the Jesuits unfolds as he observes how the priests handle this violent punishment. All the pupils must endure punishment as a result of the older boys being caught "smugging” (Joyce 38), defined in the footnotes as a homosexual act, possibly masturbation (Joyce 38). When word spreads that the priests threaten strict discipline for any infraction of the rules, Stephen cannot comprehend being included in the widespread punishment, because he has been obedient. The method of punishment the priests use is a leather baton called a pandy bat. Stephen’s classmates anticipate retribution for the sins of their classmates and predict a slew of punishments. They cope by joking, but Stephen is only an observer as he is confused about the meaning of smugging as well as the fact that his glasses are broken and his poor eyesight causes his vision to be obscured. At this point, given his diminished vision, he must rely on his sense of hearing, and his connection to sound demonstrates his uneasiness about the pandy bat:

The fellows laughed; but he felt that they were a little afraid. In the silence of the soft grey air he heard the cricket bats from here and from there: pock. That was a sound to hear but if you were hit then you would feel a pain. The pandybat made a sound too but not like that. The fellows said it was made of whalebone and leather with lead inside: and he wondered what was the pain like. There were different kinds of pains for all the different kinds of sounds. (Joyce 39) Stephen's fear mounts as his imagination anticipates how being pandied will assault his senses, and the synesthesia of equating physical pain with sound is effective in conveying 
how much the pandy bat terrifies him. At this point, Stephen is fearful of the Jesuits and their punishment. However, as Boyle reminds us, what counts is how Stephen's punishment affects his future relationship with the Jesuits. It is important to emphasize how much Father Dolan terrifies Stephen because later he will also think of him sympathetically.

Stephen's perception of the Jesuits who instruct him is challenged when he is confused by their actions. Boyle emphasizes the nuances in which Joyce's feelings about the Jesuits and Catholicism are reflected in his writing as tremendously complex in that they are not damning but instead allow for love and care between the Jesuits and their students. Father Boyle's discussion of Joyce's own relationship with the Jesuits as reflected in the literature allows for our double-sided understanding of the pandying administered by Father Dolan and witnessed by Father Arnall. Furthermore, the thirdperson limited point of view is the lens through which the reader learns of Stephen's pandying. Because of his young age, Stephen is an unreliable narrator given his limited understanding of the priest's motivation for punishing him. Father Dolan appears as a madman who refers to himself in the third person and quotes Macbeth. Father Dolan terrorizes the boys, and threatens to revisit the classroom at unpredictable times. Effectively, the punishment becomes a mental as well as physical torture. Dolan poses a terrifying figure of one who has power and is insane, "Tomorrow and tomorrow and tomorrow, said the prefect of studies. Make up your minds for that. Every day Father Dolan” (Joyce 43). Father Dolan's literary allusion summons the Macbeth of Act V who has completely lost all sense of reality in his quest for power as the King of Scotland. Conjuring Macbeth enforces the dominion of the mad priest over the helpless boys. 
However, events leading up to Stephen's pandying, such as this, are where Joyce stylistically challenges the reader to consider that while the Jesuits appear evil they cannot be entirely so, since Stephen's extreme reaction to his punishment is the reaction of a child.

Father Dolan believes Stephen deliberately breaks his glasses to get out of schoolwork. Stephen is horrified when Father Arnall does not defend his innocence. Therefore, when Father Dolan punishes Stephen, Father Arnall appears complicit since he knows that Stephen is being wrongfully accused. However, for Arnall to interject would have undermined Father Dolan's authority at a time when it was imperative that the prefect of studies crack down on the older students' recent outbreak of misbehaviors.

Author Boyle's repeated point is that Jesuit portrayal in the novel is how we come to understand Stephen, rather than a didactic representation on Joyce's part of the priests as evil:

In Portrait, far more than in Stephen Hero, the moral basis for the acts of the Jesuits, like that of humans in reality, remains mysterious. Thus Portrait emerges as literature (the same mystery of course remains for Stephen and all other human beings in the book) rather than as an illustrated anti-Catholic tract. (62) Following the punishment, Stephen deliberates that a person can be both a priest and unfair, "The prefect of studies was a priest but that was cruel and unfair” (Joyce 46). While these are the thoughts of a child, the reader can infer that the Jesuits were inflicting the discipline out of their notion of tough love. Not given a clear picture of their frame of mind allows for this contradiction. Not allowing for this duality would push an agenda 
that could take away from the literary merit of the novel. Boyle explains that portraying the priests as evil oversimplifies the complexity of their influence over Stephen:

It is reasonable and convincing that Stephen, caught in a frightening situation he could not comprehend or control, having been taught that God stood behind the priest and that the universe was governed by a fair and kind Providence, would conclude that Dolan must be evil. Joyce expresses the basis for that conclusion with concentrated power. He would in my judgment be a deficient artist if he agreed with it, and fitted his text to such agreement. (Boyle 63)

Meaning, since Boyle does consider Joyce a writer of significant literary merit, then Dolan as something other than pure evil must be considered. Within this space of ambiguity lies the complicated nature of Stephen's relationship with the Jesuits and their influence over his religious upbringing. How Stephen's perception of the Jesuits evolves is instrumental to the choices he makes regarding his position in the church. Stephen begins to think of them as men who have flaws in their own right. Considering their human fallibility makes the Jesuits less Godly in Stephen's eyes and diminishes their absolute authority over him.

Stephen reflects upon the pandying incident, and in doing so analyzes Dolan's name: "Dolan: it was like the name of a woman that washed clothes" (Joyce 48). This effectively reduces the prefect of studies from priest to washerwoman, and in doing so empowers Stephen to confront Father Conmee and complain about Father Dolan. For Stephen to break protocol and act as an emissary on behalf of his rights is bold and character defining. Stephen's brave foray into the private realm of the rector with the intent of accusing a priest of unfairness is risky, since if it backfires, he could incur the 
wrath of a vengeful Father Dolan. When the meeting is what Stephen deems a success, and he reports to the other boys that the rector will have a word with Father Dolan, he is elevated to hero status:

They made a cradle of their locked hands and hoisted him up among them and carried him along till he struggled to get free. And when he had escaped from them they broke away in all directions, flinging their caps again into the air and whistling as they went spinning up and crying: --Hurroo! (51)

By accusing Father Dolan, Stephen takes action and his first steps from underneath the umbrella of the priests' control.

Stephen's feelings for the Jesuits move from their absolute authority over him toward his understanding of their humanity. His observation of their humanity fosters his growing maturation and independence. Glimpsing the inner sanctum of Clongowes reveals the precarious seesaw on which Stephen's development rests, teetering between faith in the priests and suffocation by their doctrines. Stephen's growth toward independence is both despite and because of the priests. Chapter I of the novel concludes with Stephen’s humble reflection about his respect for Father Dolan. Following his report, and despite the unfairness of the corporal punishment, his desire for Dolan's approval confuses his young conflicted mind and, despite the lauding of his peers, he is sidelined by his inconclusive feelings as he is unable to fully despise or revere Father Dolan. "He was alone. He was happy and free: but he would not be anyway proud with Father Dolan. He would be very quiet and obedient: and he wished that he could do something kind for him to show him that he was not proud" (Joyce 51). Stephen's discomfort stems from venturing from the prescribed world of the church's authority. 
This highlights the paradox that exists within Stephen regarding his conflicting feelings toward the Jesuits as being in opposition to his independence, yet also influential to his development. Additionally, Boyle explains Joyce’s style of restraint, which allows for the incident to reveal Stephen's take on the episode as his relationship with the Jesuits evolves, instead of creating an enemy that he must push against:

The condemnation of Dolan, even in Stephen, is not absolute. This strikes me as a vitally important critical point, since a book attacking the Jesuits would not, in Stephen's definition nor in mine, be literature, but didactic or moral or pornographic exhortation to act, not to contemplate. Stephen hates Jesuits, but even Stephen knows that his hatred does not really constitute reality outside himself. So does Joyce. Joyce aims to portray Stephen and the Jesuits in the book serve that purpose. (Boyle 62)

The magnitude of this initial gesture is a clue to the hurdles Stephen must overcome as he continues to gain understanding of the Jesuits.

Stephen's sensibilities are deeply wounded when he later learns that the adults in his life find the entire meeting with the rector humorous and childish. When Stephen's father, Simon relays a conversation he has with Father Conmee years after the meeting, Stephen is ashamed and haunted by his father's lighthearted retelling of the story, "I told them all at dinner about it and Father Dolan and I and all of us we all had a hearty laugh together over it. Ha! Ha! Ha! (Joyce 63). Because Stephen’s sense of self emerges from the success of that meeting, being mocked challenges his ability to trust the priests and his father. Because the rector seemed earnest during Stephen's conversation with him, Stephen feels backstabbed by his mockery. 
For Stephen’s family, social standing is dependent upon religious affiliation, and Stephen's Catholicism as imparted to him by the Jesuits makes him a member of the educated elite. In order to ensure this stature for his child, Simon sends Stephen to boarding school at a remarkably young age:

It should be clear, then, that schools in Dublin were useful markers of social class. Stephen’s much analyzed experience at Clongowes Wood and Belvedere represented Simon Dedalus' most profound middle class ambition for his oldest son. “ ... Christian Brothers be damned! Said Mr. Dedalus. Is it with Paddy Stink and Micky Mud? No, let him stick to the Jesuits in God's name since he began with them. They'll be of service to him in after years. Those are the fellows who can get you a position.” (Ledden 333)

Like the novel's Simon, Joyce's father, John sent him to Clongowes Wood boarding school at the age of six. Joyce was two years younger than the youngest of his classmates so he resided in the infirmary for the first two years of his enrollment, "under the care of Nanny Galvin and the supervision of Brother Hanly” (Sullivan 43). If Simon is reflective of John Joyce's views, then Joyce's father regarded the Jesuits so highly that he entrusted them with rearing his son. In his discussion of Joyce during the Clongowes Wood years in his book Joyce among the Jesuits, Kevin Sullivan states, "For religion, especially as emphasized at a school like Clongowes, is likely to affect the will and the imagination of the young more acutely than spelling, sums, or geography” (42). Religion was the core of education, especially for such a young pupil. A curriculum for a child that young did not exist beyond his religious teaching, making Catholicism the paramount influence on Joyce. For those first two years, Joyce's classroom participation was with older students 
and the lessons were beyond his capabilities: "While there he had probably received his first instruction from Mr. Macardle, and probably, too, had sat in on lessons in the lowest class. But in these classes he would not have been expected to perform as responsibly as the older pupils in the benches around him” (Sullivan 43). In this way Joyce was Jesuit fashioned, primarily reared by them, not his parents. In the novel, Stephen's education at the hands of the Jesuits molds his religious sensibilities as well as establishes his standing in society. So, in addition to navigating his ambiguous religious environment, he must figure out his position at home. Just as Stephen’s understanding ofCatholicism and the Jesuits unfolds, so do his views on his family.

When Stephen observes a fight at a holiday meal, his dawning conception of the priests' fallibility is reinforced. At the same time, he begins to question the stability of his adult family members. The Christmas meal is significant because Stephen is allowed to eat with the adults for the first time. It is significant that when he is first invited to eat at the grownups' table, what erupts is chaotic disorder. Stephen’s father, Simon, and Mr. Casey delineate the Catholic priests' roles in politics while Mrs. Riordan (Dante) considers the priests the harbingers of morality for Irish Catholic culture. The importance of this issue emphasizes the fact that with Catholicism at the heart of education, Catholicism is at the root of Irish culture as the earliest molding factor for Stephen. The fight at the holiday table is a traumatic event in Stephen's development and walks the reader through his dawning cognition of the flaws in the adults who he had previously held in high esteem. An argument ensues that pits his father and Mr. Casey's politics against Dante's insistence that as representatives of God, the priests are above reproach. Following a service where the priests delivered what Simon and Mr. Casey deem a 
political agenda, Dante takes issue with any criticism by the two men regarding the priest's motivation:

--We go to the house of God, Mr Casey said, in all humility to pray to our Maker and not to hear election addresses.

--It is religion, Dante said again. They are right. They must direct their flocks. --And preach politics from the altar, is it? Asked Mr Dedalus.

--Certainly, said Dante. It is a question of public morality. A priest would not be a priest if he did not tell his flock what is right and what is wrong.

Mrs Dedalus laid down her knife and fork, saying:

--For pity' sake and for pity' sake let us have no political discussion on this day of all days in the year.

--Quite right, ma’am, said uncle Charles. Now, Simon, that's quite enough now. Not another word now.

--Yes, yes, said Mr Dedalus quickly.

He uncovered the dish boldly and said:

--Now then, who's for more turkey? (Joyce 26 - 27)

The argument escalates and allows Stephen to be privy to the complexity of each side's pain, causing a social divide. Simon and Mr. Casey feel betrayed by the condemnation of Parnell by the Church, while Dante, who previously shared their party affiliation, also put her faith in Parnell until he committed adultery at which time she followed the priests' lead, and condemned him. Simon and Mr. Casey’s opinion support a nostalgic brand of pro-Parnell nationalism, Dante believes that the priests as emissaries of God have the ultimate authority. As Stephen watches, he is understandably confused because what 
each side argues is not the opposite side of the spectrum from the other, rather nuanced shades of passionate allegiance speak to the betrayal each feels at the hands of their church and political leaders. What Stephen observes is not black and white, rather different layers of ways of thinking about the priests. Despite the fact that he notices these nuances, he still sides with Dante because at this stage in his life, the absolute righteousness of the priests is not something he is prepared to question. He weighs his feelings about Mr. Casey and Dante, "But his dark eyes were never fierce and his slow voice was good to listen to. But why was he then against the priests? Because Dante must be right then” (30). Despite the fact that his father, Simon, sides with Mr. Casey, Stephen assumes that Dante is correct in her allegiance with the priests, effectively choosing religious certitude over filial ties.

Stephen's faith in the stability of these three adults wavers when he reflects upon stories about Dante. Even though he critiques Dante he still sides with her, but reflects upon her flaws. Prior to the Christmas table fight, Stephen had regarded Dante's opinion without question, but when he sees her argue he flashes back to instances revealing her human fallibility:

Because Dante must be right then. But he had heard his father say that she was a spoiled nun and that she had come out of the convent in the Alleghanies when her brothers had got the money from the savages for the trinkets and chainies. Perhaps that made her severe against Parnell. And she did not like him to play with Eileen because Eileen was a protestant and when she was young she knew children that used to play with protestants and the protestants used to make fun of the litany of the Blessed Virgin.” (Joyce 30) 
Stephen does not delve deeper than this objective observations, but herein lies the beginning of his inability to ignore the hypocrisies that construct his authoritative figures, and allows him to question the church’s principles.

Agency from Catholic ideology is something Stephen will have to fight very hard to gain freedom from. In chapter II of this paper I will discuss Stephen’s relationship with his soul in light of potential damnation in favor of his artistic longing. My thesis for chapter II will culminate with discussion of the encounter with the Jesuit director in chapter IV of the novel. That interaction serves as the impetus of Stephen’s epiphany. Stephen will choose to sever ties with the church and his family when he convinces himself that both hinder his artistic calling. 


\section{CHAPTER TWO: Conformity \& Rebellion Leading to Epiphany}

In this chapter I will address how Stephen tests the limits of the confining structure of the Catholic framework. During this period of his growth as he moves from adolescence toward young adulthood, he both conforms with and rebels with and against his family and church. Ultimately, he has the epiphany that frees him from the confinement of Catholic Ireland. Chapter II will focus on how he reconciles with the fate of his soul. Under the umbrella of Catholicism, Stephen's ventures toward experience are sinful, so he must come to terms with the possibility of damning his soul to hell in order to be an artist. Disentangling himself from his family will be a component of this. His ultimate realization is that he has no choice but to leave. His epiphany means that leaving Ireland is an act of self-imposed exile rather than simple expatriation.

In the previous chapter, I addressed Stephen’s treatment of language, and words. Words have a power enabling him to reflect and learn. It will be through analysis of language that he will reach his epiphany. To support my discussion of Stephen's analysis of language I will cite the work of R.B. Kershner Jr. in his article, “Time and Language in Joyce’s Portrait of the Artist” in which Kershner explains:

This is the world of language. Words are embedded in and formative of his perceptions, yet they seem to have a large measure of autonomy. They have qualities which mimic those of the sensory world - the word "suck" is an example that intrigues him. They can elicit strong emotions from him, apparently through their own magic rather than through their referents; and they reveal strange associations among themselves. (607) 
I will provide textual examples of words having traumatic effects on Stephen. In fact, it will be a comment by a priest that will be the impetus of Stephen's epiphany. When the Jesuit director makes a joke about the Capuchin monks, Stephen experiences powerful flashbacks that lead to his decision that he must leaving Ireland is a necessary step toward life as an artist. I will elaborate on the exchange later in this chapter. In order to emphasize the gravity of Stephen's decision, I will provide examples of instances when Stephen attempts to conform with the expectations imposed upon him by the Catholic church. He experiments with fitting in, but when he behaves like other members of his society he is more aware than ever of his difference from them.

Stephen receives a large sum of money for excelling on his national school examinations. Given this windfall, Stephen is reckless and spends it carelessly in a manner that mirrors his father's fiscal irresponsibility. However, following Simon’s behavior makes him feel more isolated from his family rather than closer to them. Stephen is the only one of his siblings to receive the elite Jesuit-led education. As a result, he is valued as the intellectual in the family. As a scholar, he is already distanced from them, so he uses the prize money to strengthen the bonds with his family. But, the experience of lavishing them with gifts leaves him more alienated than ever, and highlights his difference rather than brings him closer to them. When Stephen wastefully spends the money on trivial items, he not only mirrors his father's irresponsibility, he realizes that buying indulgent groceries, theatre tickets, and presents for his family does not create filial ties; these acts rather emphasize his separateness from them. Although a failed attempt at being like them, his grand spree serves as a temporary distraction. His inner monologue is powerful and when the money is gone he faces the fact that he is not 
part of their world. He compares his longing for something more than his family's life to a flood that no barrier can stop (Joyce 86), and as something very powerful that he must recognize:

He saw clearly too his own futile isolation. He had not gone one step nearer the lives he had sought to approach nor bridged the restless shame and rancour that divided him from father and mother and brother and sister. He felt that he was hardly of the one blood with them but stood to them rather in the mystical kinship of fosterage, fosterchild and fosterbrother.

He burned to appease the fierce longings of his heart before which everything else was idle and alien. He cared little that he was in mortal sin, that his life had grown to be a tissue of subterfuges and falsehood. Beside the savage desire within him to realize the enormities which he brooded on nothing was sacred. (Joyce 86)

Contemplating his feelings of bitter loneliness and alienation brings him a step closer to realizing that eventually he will leave his family behind. After the money is gone, his overwhelming emotion is of alienation from the family he tried to emulate. In behaving like them, he is made keenly aware of his difference. While his family members are resigned with their socioeconomic station, Stephen sees the money as an opportunity to rise above what he considers to be an oppressive environment.

Stephen's wasteful spending of the prize money exemplifies a failed attempt to fit in and quell his artistic longing. After he is not satisfied in behaving as a member of his family, he tries rebellion. Stephen convinces himself that nothing is sacred but his longing and desire for experience. As his mission, he is willing to risk the damnation of 
his soul in order to fill this longing. As I stated earlier, in his move from adolescence to young adulthood he tries to both follow expectations as well as rebel against them. When Stephen's attempt at belonging fails, he acts out by secretly soliciting prostitutes.

Sinning means the damnation of his soul, but, rather than be deterred, he experiments with the practice of deliberately sinning. As a test, he compounds his sins with multiple transgressions, and looks inward for signs of damage to his soul during this period. As he writes in his notebook, while waiting for a prostitute named Nelly, the text he creates morphs into a soul creature with a devilish tail:

The dull light fell more faintly upon the page whereon another equation began to unfold itself slowly and to spread abroad its widening tail. It was his own soul going forth to experience, unfolding itself sin by sin, spreading abroad the balefire of its burning stars and folding back upon itself, fading slowly, quenching its own lights and fires. They were quenched: and the cold darkness filled chaos. (Joyce 90)

In this hallucination, Stephen's soul becomes a hellish beast, yet rather than fear this consequence of sin, Stephen yearns toward experience, and when he recognizes the agency of his soul he views it in a removed fashion: "The chaos in which his ardour extinguished itself was a cold indifferent knowledge of himself” (Joyce 90). Stephen pushes the limits of his soul by personifying it as something he can observe. In this experiment, because previous attempts at redemption and faith per the tenets of the Church did not assuage his longings, "His days and works and thoughts could make no atonement for him, the fountains of sanctifying grace having ceased to refresh his soul” (Joyce 90). Stephen's soul is not satisfied within the constraints of the church, and it 
longs for more, however the experiment with the prostitutes demonstrates that he cannot completely abandon the notion of his soul either. Such is his burden. The church has instilled in him a belief that if he does not follow its tenets he will go to hell; however, his longing strives beyond what Irish Catholic society deems acceptable.

I propose that Stephen's longing is to live, perceive, and come near a truth in which he can fulfill his artistic destiny. His desire is of such a magnitude that he feels compelled to risk his soul to gain some understanding of his purpose of being in the world. It is paradoxically ironic and sensible that Stephen will drastically reform on a spiritual retreat, because prior to the retreat he relishes in his rebellion: "It was strange too that he found an arid pleasure in following up to the end the rigid lines of the doctrines of the church and penetrating into obscure silences only to hear and feel the more deeply his own condemnation” (Joyce 92). Stephen’s curious mind reflects upon what he is taught, causing his intellect to question that which the doctrines do not answer. Prior to the retreat Stephen questions everything, and what he does not comprehend hangs as the sort of dead space that he longs to fill:

His mind wound itself in and out of the curious questions proposed to it. If a man had stolen a pound in his youth and had used that pound to amass a huge fortune how much was he obliged to give back, the pound he had stolen only or the pound together with the compound interest accruing upon it or all his huge fortune? If a layman in giving baptism pour the water before saying the words is the child baptized? Is baptism with a mineral water valid? (Joyce 93)

When he questions religious assumptions he is dissatisfied by the limitations of the rigid lines that he traces mentally (Joyce 93). It is as if his thoughts follow a highway that has 
been built, but lies unfinished, driving Stephen to venture beyond the constructed roadway. This is his nature, to question everything. He longs for more than the church can provide.

Thus far, I have provided examples that support the notion that internally Stephen's artistic longing compels him to push the limits of the institutions that have shaped him. Religion serves as bedrock for his society, and his perception of himself. Going forward, I will describe the experience of the retreat, its effect on Stephen's outlook, and how this reversal leads to his meeting with the Jesuit director. It will be this meeting that is the pivotal moment from which Stephen will emerge with a new exuberance and the conviction to reject Catholicism.

The drastic change in behavior Stephen undergoes during a religious retreat highlights how fearful he is of hell. Knowing that he has committed mortal sin on numerous occasions, Stephen believes hell to be a foregone conclusion. The religious retreat honoring Saint Francis Xavier, led by the rector, makes the possibility of atonement available to Stephen. The rector reminds the boys that the purpose of the retreat is to remove themselves of worldly concerns and to focus on God's will, “And remember, my dear boys, that we have been sent into this world for one thing and for one thing alone: to do God's holy will and to save our immortal souls. All else is worthless. One thing alone is needful, the salvation of one’s soul” (Joyce 96). It seems that the rector is speaking directly to Stephen when he says:

And if, as may so happen, there be at this moment in these benches any poor soul which has the unutterable misfortune to lose God's holy grace and to fall into 
grievous sin I fervently trust and pray that this retreat may be the turningpoint in the life of that soul. (Joyce 97)

The rector's words have a profound impact on Stephen, "Yes, the preacher was right. God's turn had come. Like a beast in its lair his soul had lain down in its own filth but the blasts of the angel's trumpet had driven him forth from the darkness of sin into the light” (Joyce 101). Stephen comes out of the retreat a changed young man, fearful of hell, and desirous of absolution. Hell as a consequence of mortal sin scares Stephen into making a 180-degree change in his sinful behavior. The damnation of his soul and eternal hell are not metaphor to Stephen, and God is only forgiving as long as one has time to repent and give confession. That is why, following the sermon, which covers all manner of tortures in hell from darkness, to odor, to heat, Stephen is urgent to confess and dedicate his life to saving his soul. In religion, he thinks he has found a much more clearly defined path.

In the period after the retreat, he rejects his inner artist and attempts to adhere to the tenets of Catholicism. The retreat frightens him into religious adherence. He becomes convinced that redemption is possible and that he must dedicate himself to atoning, lest he risk hell. With this in mind he must set aside his artistic longing. Stephen, once again, attempting to conform and place himself within his religious community thinks about being part of the cycle of life. While in class, learning about historical figures, Stephen muses about the temporality of life as opposed to an eternal afterlife, "All had died: all had been judged. What did it profit a man to gain the whole world if he lost his soul? At last he had understood: and human life lay around him, a plain of peace whereon antlike men laboured in brotherhood, their dead sleeping under 
quiet mounds” (Joyce 110). Such is his mindset as he suppresses his questioning and artistic side in an attempt to align his ideology and lifestyle in a virtuous manner. With his newfound commitment to care for his soul, he stops looking for truth in his soul, and follows the rules of the church. By ceasing to privilege learning and truth seeking, Stephen tamps down his longing and replaces it with a commitment to dedicate his life to God. Stephen believes this will safeguard his eternal soul.

However, his artistic longing is strong despite his best efforts to resist it. In chapter IV Stephen practices a regimented, religiously prescribed life in his newfound attempt at conformity. This discipline is doomed because his artistic longing pushes back against the Catholic frame. Nevertheless, Stephen attempts to privilege his soul over his art by living a pious routine: "Sunday was dedicated to the mystery, of the Holy Trinity, Monday to the Holy Ghost, Tuesday to the Guardian Angels, Wednesday to saint Joseph, Thursday to the Most Blessed Sacrament of the Altar, Friday to the Suffering Jesus, Saturday to the Blessed Virgin Mary” (Joyce 128). This new lifestyle is one of checks and balances where Stephen feels that, with every devotion, he is making purchases toward his stake in heaven (Joyce 129). No longer does he have time for musing. Where his mind used to reach, it now reminds itself that whenever it questions or posits intellectual theories that is due to his own ignorance as a sinner. He tries to convince himself to have faith in the notion that with time he will be religiously enlightened.

Consequently, Stephen struggles between feelings of rapture and entrapment, so that, in his struggle to follow God, he inflicts more discipline into his routine by controlling his senses, "But it was the mortification of touch that he brought the most assiduous ingenuity of inventiveness. He never consciously changed his position in bed, 
sat in the most uncomfortable positions, suffered patiently every itch and pain, kept away from the fire” (Joyce 131). Stephen’s tactics keep him on what he believes to be the path to religious salvation, but, redemption is not that easy for Stephen. As I previously stated, he fluctuates between feelings of satisfaction and temptation, and he finds pleasure in the proximity of sin and his ability to resist it:

Then, almost at the instant of that touch, almost at the verge of sinful consent, he found himself standing far away from the flood upon a dry shore, saved by a sudden act of the will or a sudden ejaculation: and, seeing the silver line of the flood far away and beginning again its slow advance towards his feet, a new thrill of power and satisfaction shook his soul to know that he had not yielded nor undone all. (Joyce 133)

This gives one a glimpse of Stephen's play with his soul, in fact manipulating and toying with it, revealing how much his soul is part of his consciousness. And, while outwardly he might demonstrate the epitome of piety, inwardly he questions whether or not he has really amended his life (Joyce 134). It would be much easier to comply with the tenets of Catholicism, but his nature does not allow him blindly to follow the doctrines. Kershner reminds us that despite Stephen's attempts at piety they run counter to the church's aim: Stephen's religious quest is foredoomed by his only possible mode of authentic experience. It is only in "sacrificial or sacramental acts," single discrete moments of ritual, that his soul is "drawn to go forth to encounter reality” (p. 159). The Church, on the other hand, is not concerned with moments, or even with experienced time; as the retreat sermon makes clear, Eternity is the Church’s concern. (611) 
Stephen is neither unable to view the world through a Catholic lens, nor can he not scrutinize his world. In his attempt at religious adherence, Stephen is missing the point. While he thinks he is being dutiful he is just temporarily ignoring his longing.

The turning point occurs when Stephen has his epiphany follows his meeting with the Jesuit director in the fourth chapter of the novel. Stephen's epiphany develops out of words, and causes him to realize he must sacrifice his soul in favor of his art and life. In the meeting, the priest subtly induces Stephen to join the Jesuits, and makes a joke about the Capuchin monks, it is this joke that catapults Stephen into an epiphany. His epiphany is his realization that he must leave Ireland, and the church in order to live as an artist. The Capuchins are priests and friars whose special ministry is to the poor, including people living on the margins of society, while the ministry of the Jesuits focuses on education and scholarship. The habits worn by Capuchins are intended to mimic the humble attire of a hermit. The long brown uniform belted with a cord is what the Jesuit director in Portrait chastises in his joke:

Stephen's face gave back the priest's indulgent smile and, not being anxious to give an opinion, he made a slight dubitative movement with his lips. --I believe, continued the director, that there is some talk now among the capuchins themselves of doing away with it and following the example of the other Franciscans.

--I suppose they would retain it in the cloister, said Stephen.

--O certainly, said the director. For the cloister it is all right but for the street I really think it would be better to do away with it, don't you?

--It must be troublesome, I imagine. 
--Of course it is: of course. Just imagine, when I was in Belgium I used to see them out cycling in all kind of weather with this thing up about their knees! It was really ridiculous. Les jupes, they call them in Belgium.

--O. (Joyce $134-135)$

During this scene, Stephen follows the protocol of polite discourse as the priest makes conversation. Stephen does everything right in the discussion led by the director regarding the attire worn by Capuchin monks. He diplomatically does not commit to either being in favor of or against their attire, and skillfully makes the right facial gestures and speaks in a noncommittal, yet polite fashion. However, the priest's offhanded remark making fun of the Capuchins sends Stephen spiraling into a reverie reminding him about women's stockings and horses' reins not feeling the way he imagined they would. It appears that the director is making this snide comment in order to gauge how well Stephen fits in with casual discourse among priests . The priest is deliberate in this conversation, because while it seems a trivial comment, it is a test.

Analysis of the priest's offhanded joke about the Capuchins is helpful in understanding its impact on Stephen's decision to leave the church. Instead of ignoring the joke, he reflects upon instances of appearances countering reality, and in this way begins to reject the construct of the church and the notion of becoming a Jesuit himself. By remembering other instances of being let down when what he imagined clashed with reality, he is able to see that the Jesuits are not impervious to human failings, and that the construct of the religion is flawed as well. At no time does he relinquish his fear of hell and the notion of his soul's eternal damnation. It is the Catholic framework and Jesuit priests that he will no longer abide. The effects of the priest's language on Stephen's 
perception are significant because close analysis of words is how Stephen finds meaning. Kershner describes the manner that words impact Stephen’s perception, "But words, more often than they provide 'glimpses of the real world,' provide an incantatory barrier between himself and that world, a sort of refuge in subjectivity" (607). When the director describes the monks as les jupes (in English, the skirts) Stephen's shock is not about the joke, but the joke acts as the catalyst that causes him to reflect on instances of appearances countering realities. A woman's stockings and a horse's reins seem mundane as a joke, however the effect of a real world object not holding up to what Stephen's imagination has conjured helps him consider the fallacy of Catholicism.

The mention of les jupes reminds Stephen of instances when he envisioned the way stockings and reins would feel to the touch, only to be "shocked" (Joyce 135) when they are not as he imagined. By feminizing the Capuchins with this nickname, the priest has reduced them to an article of clothing worn by women, leading Stephen to think about women's stockings and equine tack. The repetition of the word shock in the passage emphasizes the extent to which Stephen relies on his imagination and interior world for answers, because it shocks him when the fantasy is out of sync with reality: The names of articles of dress worn by women or of certain soft and delicate stuffs used in their making brought always to his mind a delicate and sinful perfume. As a boy he had imagined the reins by which horses are driven as slender silken bands and it had shocked him to feel at Stradbrooke the greasy leather of harness. It had shocked him too when he had felt for the first time beneath his tremulous fingers the brittle texture of a woman's stocking for, retaining nothing of all he read save that which seemed to him an echo or a 
prophecy of his own state, it was only amid softworded phrases or within rosesoft stuffs that he dared to conceive of the soul or body of a woman moving with tender life. (Joyce 135)

Interlacing the imagery of the reins with the stockings superimposes a memory of Stephen's that is very visceral and impacted by the liquids of other beings. While women wear stockings, the white markings on horses' legs are also called stockings. It is important to remember here that Stephen's interaction with women was with prostitutes. While the finest cotton stockings in the world at that time would have been available to Irish women coming from Balbriggan, Ireland (http://visitbalbriggan.com/learn/hosierylinen-businesses/), the prostitutes stockings would not be supple. Unwashed stockings would become stiff or brittle from sweat and semen. Also incongruent are the reins, horses at Stradbrooke would be associated with racing and betting. In that atmosphere horses are whipped to a point that the friction from their sweat and the harness would create a foam that indeed results in greasiness. Like the stockings and the reins, the application of les jupes to the monks implies a tawdriness that forces Stephen to contemplate that the priest is capable of meanness.

The deliberateness of this seemingly offhanded remark is part of the manner in which Stephen is vetted. That one comment - les jupes - also spurs flashbacks of suppressed memories of the priests making very human errors in his estimation, and as with the stockings and the reins, he no longer can have faith in the Jesuits. Accepting the priests as flawed conveys what Boyle calls a respect for human mystery:

Joyce's text leaves us precisely where reality outside ourselves (and inside too, for that matter) leaves us — unable with certitude to judge whether any given 
human is ultimately worthy of condemnation or of approval. We can of course guess, and it is sometimes fun to do that—and sometimes necessary. But if we insist that we have, in spite of the cloud of facts and unfacts we cannot reach or know, attained to objective certitude before which all must bow, then we truly are expository asses. (70)

While Father Boyle is discussing the experience of the reader and the critic in approaching Joyce's characters, his anlysis mirrors Stephen's experience as his understanding of the Jesuits changes. Complicating Stephen's newfound notion of the order, is the fact that there is something flattering about being let in on a joke. Furthermore, for the director to recognize Stephen as a potential priest demonstrates that Stephen is a standout. Unfortunately, the exemplary pious behavior that makes Stephen appear to be an ideal candidate, is completely counter to his inquisitive nature that strives toward artistic longing.

It is with some sadness that Stephen acknowledges the priests' failings and inconsistencies, "Lately some of their judgments had sounded a little childish in his ears and made him feel a regret and pity as though he were slowly passing out of an accustomed world and were hearing its language for the last time” (Joyce 136). In fact, this is the shift in Stephen's young adult life, for he can no longer abide by the teachings of the priests, and must forge his future originally and without the structure of religion. Stephen is dutiful so that when the priest asks if he has ever considered joining the order, Stephen answers that he has (Joyce 137). As Stephen exits the priest's office and briefly contemplates becoming a Jesuit, he feels as if he is suffocating: 
A feverish quickening of his pulses followed and a din of meaningless words drove his reasoned thoughts hither and thither confusedly. His lungs dilated and sank as if he were inhaling a warm moist unsustaining air and he smelt again the warm moist air which hung in the bath in Clongowes above the sluggish turfcoloured water. (Joyce $140-141$ )

The order will suffocate Stephen and his physical reaction to this possibility creates a bodily response to breathe. Therefore he decides to reject the priesthood, and all of the rituals of Catholicism.

Stephen is truthful when he tells the director that he had considered the vocation of a Jesuit priest; however, as evidenced by a daydream, Stephen has always thought of the priesthood as an aesthetic tableau instead of as religious calling:

His soul had loved to muse in secret on this desire. He had seen himself, a young and silent mannered priest, entering a confessional swiftly, ascending the altarsteps, incensing, genuflecting, accomplishing the vague acts of the priesthood which pleased him by reason of their semblance of reality and of their distance from it. (Joyce 138)

His attraction to the order is superficial and counters his more powerful motivation, which is not easily defined by rituals and routine; rather it is his pursuance of the intangible that lies at the root of his longing for artistic realization:

In vague sacrificial or sacramental acts alone his will seemed drawn to go forth to encounter reality: and it was partly the absence of an appointed rite which had always constrained him to inaction whether he had allowed silence to cover his anger or pride or had suffered only an embrace he longed to give. (Joyce 139) 
Because his will is compelled to seek reality, even in fantasy, the imagined priest he sees himself as is incomplete. The silent unanswered space that envelops his daydream is a problematic barrier, which until his epiphany inhibits Stephen's ability to go forth. When he emerges from the director's office he is immersed in the grit of the world and rather than be depressed by the humble cottages and reeking cabbages, he is compelled to laugh spontaneously (Joyce 142). While the priest's pitch is laden with the power of the priesthood to be emissaries of God, Stephen's indecision is over and he realizes he will venture purposely into a life without religion, "His destiny was to be elusive of social or religious orders. The wisdom of the priest's appeal did not touch him to the quick. He was destined to learn his own wisdom apart from others or learn the wisdom of others himself wandering among the snares of the world” (Joyce 141 - 142). Stephen stops fluctuating between religious conformity and rebellion. His epiphany effectively drives him toward an understanding that his art will prevail, but not within the confines of Catholic Ireland. 


\section{CONCLUSION}

Stephen's epiphany in the director's office convinces him that leaving his community is possible and necessary to pursue his life as an artist. He decides that he must leave Catholic Ireland in order to fulfill his longing to delve into what life has to offer away from his home. He does not name what he longs for, because he does not yet know exactly what he desires. As the novel's title reminds us, he is a young man about to embark on his great adventure. In the scenes following his departure from the meeting with the director, the imagery of darkness recurs as symbolic of his unknown future. Stephen resists investigating the darkness, because first, he must negotiate the terms of his exile. Following his epiphany, Stephen deliberately disengages from his siblings, peers, mother, and church. He mentally notes how different his outlook is from theirs, reinforcing his realization that he does not belong in their world. By releasing himself from the institutions of community, family and church he is free to disembark and plunge into the dark unknown future.

Exile is not an act of rebellion against his Catholic culture, rather exile is the necessary outcome of his inability to flourish as an artist within its framework. Michael Gillespie’s book James Joyce and the Exilic Imagination contends that exile can be both forced upon a person and self-imposed:

An external entity may impose a condition that a person's life in his or her native country has become insupportable, or the individual may come to that sense of intolerability from within. In either case, it is the conditions and one's perception of them, and not their source, that form one’s sense of being an exile. (3) 
This speaks to what has troubled Stephen throughout his life. While he is filled with great longing and a compulsive desire to experience life and create art, he feels the barriers of Catholic Ireland inhibit his artistic fruition. Going forth, Stephen will embrace all aspects of experience, including sins, and therefore he must acknowledge his inability to flourish within a construct that prohibits that explorative lifestyle.

When Stephen realizes that leaving Ireland is inevitable, he feels relieved. Stephen's epiphany results in optimism, and the conviction that he must sever his ties with Catholicism, which, in addition to the Catholic church, encompasses his family, friends, and country. It is important to note that it would be too easy to say that Stephen no longer believes in these, rather the established rituals, which support the institutions of religion, family, and nation are too confining for Stephen who can no longer adhere to their dogmatic principles. Stephen does not eschew these institutions lightly, rather he considers their ponderous weight as important, but impossible to obey. In his rejection, he privileges his artistic future over his soul, “despite the trauma inherent in the experience, it is a mistake to assume that the exile's feelings can be summed up sufficiently from a single, simple, negative perspective” (Gillespie 8). While Stephen is critical of his homeland's barriers, accepting exile as inevitable liberates him. His newfound autonomy follows a childhood and adolescence riddled with confusion and frustration. With a state of mind that demonstrates conviction, as well as affection, Stephen mentally says his goodbyes to his family, friends, and country. These personal goodbyes are necessary for his departure.

Following the meeting with the director detailed in chapter two, Stephen goes home and joins his siblings in his parents' kitchen. He observes his place among them 
and realizes that his reaction to his parents' impending eviction is different from theirs. While the siblings accept another forced move as a routine they will doggedly endure, Stephen is unable to give up on a fulfilling life that offers the opportunity to satisfy his artistic longing. Acknowledging this difference confirms his notion that his destiny will be unique from theirs. While they are hardened and resigned, he seeks the endless possibilities of an unknown future. Stephen takes note of the effect of life's hardships on them, "All that had been denied them had been freely given to him, the eldest: but the quiet glow of evening showed him in their faces no sign of rancour” (Joyce 142 - 143). While the younger siblings accept the eviction, Stephen is filled with the shameful memory of a classmate's inquiry as to why his family moved so frequently, "Still another removal! A boy named Fallon in Belvedere had often asked him with a silly laugh why they moved so often. A frown of scorn darkened quickly his forehead as he heard again the silly laugh of the questioner" (Joyce 143). Stephen was embarrassed when the classmate caught on to his family's financial instability, and upon hearing of another move, he is transported in memory to that experience. His siblings are hardier and resilient and playfully reply to Stephen in Pig Latin, "Becauseboro theboro landboro lordboro willboro putboro usboro outboro” (Joyce 143). Stephen’s siblings are not tortured by their intellect or longing as he is. The fact that they can jest, even if sardonically, underscores their ability to survive their harsh environment in a way that Stephen cannot.

Interacting with his siblings, and noting their inability to combat life's difficulties, reinforces his assertion that he cannot remain. This acknowledgement enables his detachment from them. It is possible for Stephen to simultaneously reject his siblings' 
resignation while also looking upon them fondly. Ambiguous feelings are a component of each personal rendering he facilitates in his preparation to leave Ireland.

Despite the subjectivity of all artistic expression, creations shaped by the exilic experience come out of the same fundamental sense of separation, grounded in feelings of nostalgia and/or rancor. The exilic condition inclines the individual, particularly if that person is a writer, simultaneously toward backward and forward visions. The traumatic parting from the homeland severs the physical ties to a place even as the terms of that separation reaffirm an emotional bond to what is now lost. (Gillespie 11)

Stephen watches his siblings before singing along with them, his mood is reflective, and his perspective is that of one sitting on the periphery. The emotional bond that Gillespie writes of is evident as Stephen observes his siblings with sympathy. His siblings begin singing "Oft in the Stilly Night” a song by Thomas Moore with lyrics that betray a bitterness and sadness that should be beyond their years, "Thus, in the stilly night,/Ere slumber's chain hath bound me,/Sad Memory brings the light/Of other days around me” (james-joyce-music.com). Their choice of song emphasizes a tedious and perpetual struggle. The combination of childishly speaking Pig Latin, followed by singing about weariness at the end of the day, is poignant for Stephen because although he eventually joins in the singing, he does not share their acceptance of this way of life. "He waited for some moments, listening, before he too took up the air with them. He was listening with pain of spirit to the overtone of weariness behind their frail fresh innocent voices. Even before they set out on life's journey they seemed weary already of the way” (Joyce 143). Detaching from his family is traumatic, but also essential in that if he stays, his artistic 
aspirations will die. Stephen stands in contrast to his siblings, in that where they unwaveringly face their lack of education and impending eviction without rancor, he would become embittered and would suffer if forced to stay.

In a similar fashion, Stephen disengages from his peers. For example, when he watches them at play he realizes that he is not only leaving them behind, but his childhood as well. Stephen observes his friends swimming in the river, and they symbolically crown him by calling him Stephanos, which is Greek for wreath or crown (Joyce 148). "Their banter was not new to him and now, as always, it flattered his mild proud sovereignty. Now, as never before, his strange name seemed to him a prophecy” (Joyce 148). This Stephen is far different than the Stephen of his youth who tried to fit in with the masses. This Stephen embraces his peripheral vantage as he detaches from his community of peers. As he retreats he delves internally and feels euphoric, imagining a hawk man flying out of the sea, "a hawklike man flying sunward above the sea, a prophecy of the end he had been born to serve and had been following through the mists of childhood and boyhood, a symbol of the artist forging anew in his workshop out of the sluggish matter of the earth a new soaring impalpable imperishable being?” (Joyce 148). With his friends' voices in the background, Stephen's soul soars representing his departure from their juvenile banter:

--One! Two! ... Look out!

--O, Cripes, I’m drownded!

--One! Two! Three and away!

--Me next! Me next!

--Stephaneforos! 
His throat ached with a desire to cry aloud, the cry of a hawk or eagle on high, to cry piercingly of his deliverance to the winds. This was the call of life to his soul not the dull gross voice of the world of duties and despair, not the inhuman voice that had called him to the pale service of the altar. An instant of wild flight had delivered him and the cry of triumph which his lips withheld cleft his brain.

--Stephaneforos! (148)

When he imagines himself as a hawk, he propels himself from the world of his peers. As the unknown beckons, he imagines his future as an alluring unknown that he must eschew until he is finished with his partings from family, community, and church.

Stephen contemplates darkness and the unknown as he prepares to venture from Ireland. In those dark spaces lie his unknown future. He resists the urge to plunge into that dark spaces he imagines, because first, he must separate himself from his community. In these instances he acknowledges the dark space but temporarily rejects it, even though that darkness keeps making itself available to his thoughts. When Stephen thinks of his friend, Cranly, he deconstructs the pieces of his friend's face, contemplating his dark eyes, but Stephen refuses to dwell in the dark unknown, "Through this image he had a glimpse of a strange dark cavern of speculation but at once turned away from it feeling that it was not yet the hour to enter it” (Joyce 156). His exile is imminent, but first he must cut these ties. Additionally, Stephen severs himself from Dublin. He does this by analyzing the language of his community until it becomes incomprehensible to him. Following his thoughts of Cranly he analyzes the language of Dublin, and how it limits his consciousness, thereby also restricting him as an artist: 
But the nightshade of his friend's listlessness seemed to be diffusing in the air around him a tenuous and deadly exhalation: and he found himself glancing from one casual word to another on his right or left in stolid wonder that they had been so silently emptied of instantaneous sense until every mean shop legend bound his mind like the words of a spell and his soul shrivelled up sighing with rage as he walked on in a lane among heaps of dead language. His own consciousness of language was ebbing from his brain and trickling into the very words themselves which set to band and disband themselves in wayward rhythms:

The ivy whines upon the wall

And whines and twines upon the wall

The ivy whines upon the wall

The yellow ivy on the wall

Ivy, ivy up the wall.

Did any one ever hear such drivel? Lord Almighty! (Joyce 156)

In hyperanalyzing the language, he finds it difficult to form words into anything significant. Dismantling his language will clear a path for inspiration. Stephen is not discouraged by his bad poetry above. He knows he is leaving an uninspiring environment, and can look forward to future creativity elsewhere.

Stephen's quarrel with his mother over his refusal to attend the Eucharist enables him to reconcile his departure from the church. It is not his mother's insistence that drives him away from Ireland, rather his fear of the church's power over its citizens. Walking and talking with his friend, Cranly, Stephen is forced to put his fear into words. The outcome of the conversation is that Stephen announces he must leave. Cranly 
disapproves of Stephen's refusal to oblige his mother's wishes, and imagines it is due to his disbelief in the practice. Cranly appeals to Stephen's sense of sympathy for his mother who has had a difficult life, and the crux of his appeal is that she asks little of her son. "Then do so, Cranly said. Do as she wishes you do. What is it for you? You disbelieve in it. It is a form: nothing else. And you will set her mind at rest” (Joyce 213). A debate between the two young men ensues. Stephen cites instances when famous Catholics did not deign to touch their mothers. Stephen's intention in aligning with venerated Catholics is to highlight the hypocrisy of the church. Stephen adds Jesus as another example of a figure who treats his mother poorly, "Jesus too seems to have treated his mother with scant courtesy in public but Suarez, a Jesuit theologian and Spanish gentleman, has apologized for him” (Joyce 214). What is interesting, and why I bring up this exchange is the way in which Cranly turns Stephen's syllogism against him. Stephen contends that if Jesus shuns his mother and is deemed holy, and if Stephen shuns his mother and is deemed a sinner then the church is a hypocrite. But, when Cranly raises the possibility of Jesus' fallibility, Stephen is uncomfortable, because despite his instigating examples, he is not a nonbeliever. This is revealed following Cranly's statement, "I mean, Cranly said, hardening in his speech, did the idea ever occur to you that he was himself a conscious hypocrite, what he called the jews of his time, a whited sepulcher? Or, to put it more plainly, that he was a blackguard?” (Joyce 214). When Stephen is bothered by this statement, Cranly realizes that Stephen does believe in Catholic principles:

--And why were you shocked, Cranly pressed on in the same tone, if you feel sure that our religion is false and that Jesus was not the son of God? 
--I am not at all sure of it, Stephen said. He is more like a son of God than a son of Mary.

--And is that why you will not communicate, Cranly asked, because you are not sure of that too, because you feel that the host too may be the body and blood of the son of God and not a wafer of bread? And because you fear that it may be? --Yes, Stephen said quietly. I feel that and I also fear it.

--I see, Cranly said. (Joyce 214)

Such are the stakes in his refusal to take part in the Eucharist. Stephen is afraid, and therefore cannot carelessly take the host to appease his mother. His fear is complex, because he also feels that taking the host is an act of conformity that he cannot abide.

When Cranly questions him, Stephen reveals that his fear is doubly burdensome because he fears taking the host would also be a catalyst toward conformity. By bowing down to religious practice, he would lose his newfound autonomy, and his soul would suffer the fate of the masses from whom he recently distinguished himself. When Cranly asks Stephen to elaborate on his fear, the pervasiveness of Catholicism's influence over Stephen is evident in his response:

--Do you fear then, Cranly asked, that the God of the Roman catholics would strike you dead and damn you if you made a sacrilegious communion? --The God of the Roman catholics could do that now, Stephen said. I fear more than that the chemical action which would be set up in my soul by a false homage to a symbol behind which are massed twenty centuries of authority and veneration. (Joyce 215). 
Stephen feels that taking the host would begin a chain of events that would be detrimental to his artistic future. He fears the consequences of insincere participation in the Eucharist, because if he follows this practice, he will landslide into all the other aspects of life in Ireland that he is desperate to escape. As Cranly struggles to understand Stephen's determination to leave and questions him, Stephen makes clear that it is, in fact, impossible to stay.

I will not serve that in which I no longer believe whether it call itself my home, my father land or my church: and I will try to express myself in some mode of life or art as freely as I can and as wholly as I can, using for my defense the only arms I allow myself to use, silence, exile and cunning. (Joyce 218)

What follows are days noted in a diary as a countdown to his leaving. With the third to the last entry titled, "16 April: Away! Away!,” he is ready. In fact the dark unknown that he resisted previously he now embraces as he imagines a white roadway, and dark ships that will carry him away from his world. "The spell of arms and voices: the white arms of roads, their promise of close embraces and the black arms of tall ships that stand against the moon, their tale of distant nations. They are held out to say: We are alone. Come” (Joyce 223). With this abandon Stephen prepares to embark on his adventure. My project in writing this thesis was to chart the trajectory of Stephen's development from his Jesuit-sheltered boyhood to the unfettered young man who readily embraces a world of possibilities. His artistic longing, which I have written so much about, drives him to forsake his community and God in pursuance of the realness of experience that Catholic Ireland can not provide. Joyce leaves the reader with many unanswered questions about 
Stephen's fate, but this is not his whole story, rather only a portrait of him as a young man. 


\section{REFERENCES}

Boyle, Robert R. James Joyce's Pauline Vision: A Catholic Exposition. Carbondale: Southern Illinois UP, 1978. Print.

Ellmann, Richard. James Joyce. New York: Oxford UP, 1959. Print.

Fargnoli, A. Nicholas., Michael Patrick. Gillespie, and A. Nicholas. Fargnoli. Critical Companion to James Joyce: A Literary Reference to His Life and Work. New York, NY: Facts On File, 2006. Print.

Gillespie, Michael, James Joyce and the Exilic Imagination. University Press of Florida: Gainesville, 2015. Print.

Joyce, James, A Portrait of the Artist as a Young Man: Authoritative Text, Backgrounds and Contexts, Criticism. New York: W.W. Norton, 2007. Print.

Kearney, Richard. Modern Movements in European Philosophy. Manchester: Manchester UP, 1994. Print.

Kershner, R. B. "Time and Language in Joyce's Portrait of the Artist." Elh 43.4 (1976): 604-19. JSTOR. Web. 27 Apr. 2015. <http://www.jstor.org/stable/2872740>.

Ledden, Patrick J. "Education and Social Class in Joyce's Dublin." Journal of Modern Literature Joyce and the Joyceans 22.2 (1998-1999): 329-36. JSTOR. Web. 4 May 2015. <http://www.jstor.org/stable/3831738>.

McCourt, John. The Years of Bloom: James Joyce in Trieste, 1904-1920. Dublin: Lilliput, 2001. Print.

Mezey, Jason Howard. "Ireland, Europe, the World, the Universe: Political Geography in "A Portrait of the Artist as a Young Man"' Journal of Modern Literature Joyce and the Joyceans 22.2 (1998-1999): 337-48. JSTOR. Web. 4 May 2015.

$<$ http://www.jstor.org/stable/3831739>.

Singer, Thomas C. "Riddles, Silence, and Wonder: Joyce and Wittgenstein Encountering the Limits of Language." Elh 57.2 (1990): 459-84. JSTOR. Web. 4 May 2015. $<$ http://www.jstor.org/stable/2873080>.

Sullivan, Kevin. Joyce Among the Jesuits, New York: Columbia University Press, 1957. Print 